\title{
Sekolah Berbasis Boarding School dalam Pembentukan Karakter Sosial Peserta Didik
}

\author{
Salwia $^{1}$, Hamsu Abdul Gani ${ }^{2}$, Suardi $^{3}$ \\ ${ }^{123}$ Pendidika IPS Terpadu, Ilmu Pengetahuan Sosial, Universitas Negeri Makassar, Indonesia \\ Email : Salwia.mansyur@gmail.com ${ }^{1}$,
}

\begin{abstract}
Abstrak. Penelitian ini bertujuan untuk mengetahui 1) Pelaksanaan kegiatan sekolah berbasis boarding school dalam pembentukan karakter sosial peserta didik di SMA Negeri 17 Makassar. 2) Karakter sosial peserta didik yang mengikuti boarding school di SMA Negeri 17 Makassar. Penelitian ini menggunakan penelitian kualitatif yang melibatkan 15 orang sebagai informan (10 orang peserta didik, 4 orang pembina asrama, dan kepala sekolah). Data penelitian ini dikumpulkan melalui observasi, wawancara, dan dokumentasi. Teknik pengabsahan data yaitu triangulasi sumber dan triangulasi teknik. Hasil penelitian menunjukkan bahwa (1) Pelaksanaan kegiatan sekolah berbasis boarding school dalam pembentukan karakter sosial peserta didik di SMA Negeri 17 Makassar meliputi bimbingan keagamaan, pengembangan bakat dan minat, keterampilan sikap prososial dan bimbingan belajar. Selain kegiatan asrama juga terdapat penerapan tata tertib, pemberian hukuman yang konsisten sesuai dengan tingkat pelanggaran sebagai rangkain pelaksanaan kegiatan sekolah. (2) Karakter sosial peserta didik yang mengikuti boarding school di SMA Negeri 17 Makassar dapat dilihat dari segi kejujuran kurang baik karena masih terdapat peserta didik yang tidak memiliki perilaku jujur. Dari segi toleransi, peserta didik saling menghargai dan menghormati tanpa membeda-bedakan keyakinan. Dari segi demokratis, pengambilan keputusan selalu diputuskan bersama. Dari segi semangat kebangsaan, selalu memperingati hari nasional. Dari segi peduli lingkungan, selalu menjaga kebersihan dan keamanan asrama. dari segi peduli sosial, melaksanakan kegiatan baksos. Dari segi tanggung jawab, melaksanakan dengan baik segala kegiatan dan dari segi kerjasama, peserta didik saling membantu melakukan segala kegiatan seperti kerja bakti.
\end{abstract}

\section{Kata Kunci : Boarding School, Karakter Sosial}

Abstract. This study aims to axamine 1) the implementation of school activities that based on boarding school system in building the social character of students at SMAN 17 Makassar and 2) the social character of students who participate in boarding school at SMAN 17 Makassar. This study uses qualitative research involving 15 people as the informants (10 students, 4 boarding supervisors, and school's principal). Research data were collected through observation, interviews, and documentation. The data validation techniques is source triangulation and technique triangulation. The results of the study indicate that (1) the implementation of school activities based on boarding school system in building the social character of students at SMAN 17 Makassar include guidance religious, the development of interest and talent, skill attitude prososial and early education of trustees dormitory under direction. Then other than activities dormitory there are also the application of good governance dormitory, the provision of punishment consistent in line with the rate an offense as a series of the implementation of the school activities based boarding school done in senior high school 17 Makassar. (2) the social 
character of the educated student attending boarding school can be seen from poor honest activity because of the lack of honest behavior the student has. In terms of transparency, leaners honor and respect each other without differentiating beliefs. Democratically, decision making is always decided together, in terms of nationalistic fervor, and it celebrates national day. In terms of environmental care, always maintain the cleanliness and safety of the dorms. In a social sense, performing charitable functions. In a sense of responsibility, executing all activities well and in cooperation, learners help each other with such activities as charitable work.

Keywords: Boarding School, Social Character

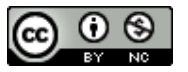

Ini adalah artikel dengan akses terbuka dibawah licenci CC BY-NC-4.0

(https://creativecommons.org/licenses/by-nc/4.0/ ).

\section{PENDAHULUAN}

Pendidikan merupakan sarana penting untuk meningkatkan kualitas sumber daya manusia. Untuk memaksimalkan Pendidikan, ditetapkan jalur Pendidikan formal yang mewajibkan anak mengenyam dunia pendidikan yaitu sekolah dasar sampai menengah. Kegiatan pendidikan formal yang berlangsung secara berjenjang pada hakikatnya dimaksudkan untuk mewujudkan tujuan pendidikan nasional sebagaimana ditegaskan dalam UU No 20 Tahun 2003 pasal 3.

Sekolah berperan sebagai lingkungan ke dua bagi peserta didik terutama dalam membentuk karakter yang berkualitas dan bermartabat. Maka dari itu pendidikan di sekolah tidak hanya terkait upaya penguasaan di bidang akademik oleh peserta didik, namun harus diimbangi dengan pembentukan karakter.

Kehidupan seseorang dipengaruhi oleh karakter yang kuat. Menurut Creasy (Zubaedi, 2011: 16) Pendidikan karakter merupakan upaya mendorong peserta didik tumbuh dan berkembang dengan kompetensi berfikir dan berpegang teguh pada prinsip-prinsip moral dalam hidupnya serta keberanian melakukan yang benar meski dihadapkan pada tantangan.

Pada dasarnya karakter seseorang dapat dibentuk melalui perencanaan yang matang, pelaksanaan dalam sebuah kegiatan yang dilakukan secara berulang dan lambat laun sebagai kebiasaan dan membentuk suatu karakter. Keseimbangan pendidikan karakter dan pembentukan karakter perlu diperhatikan oleh pendidik di sekolah. Pada Lembaga pendidikan formal salah satu inovasi yang dilakukan adalah menggunakan sekolah berbasis boarding school.
SMA Negeri 17 Makassar merupakan salah satu sekolah yang menerapkan sekolah asrama (boarding school) dan menjadi sekolah percontohan oleh dinas Pendidikan Provinsi Sulawesi Selatan. Pembentukan karakter sosial dibentuk agar peserta didik mampu menjaga sikap terhadap sesamanya, baik dilingkungan asrama, sekolah, maupun di masyarakat. Oleh karena itu peneliti tertarik untuk mengkaji lebih dalam permasalahan "Sekolah Berbasis Boarding School dalam Pembentukan Karakter Sosial Peserta Didik di SMA Negeri 17 Makassar." Berdasarkan uraian tersebut maka tujuan penelitian ini adalah untuk mengetahui:

1. Pelaksanaan kegiatan sekolah berbasis boarding school dalam pembentukan karakter sosial peserta didik di SMA Negeri 17 Makassar.

2. Karakter sosial peserta didik yang mengikuti boarding school di SMA Negeri 17 Makassar.

\section{TINJAUAN PUSTAKA}

a. Teori Pendidikan Karakter Thomas Lickona

Pendidikan karakter telah menjadi perhatian berbagai negara dalam rangka mempersiapkan generasi yang berkualitas, bukan hanya untuk kepentingan individu warga negara, tetapi juga untuk warga masyarakat secara keseluruhan. Menurut Lickona (1992) "peduli sosial peserta didik sebenarnya harus dibangun sejak dini karena kehidupannya akan semakin kompleks seiring dengan pertumbuhan dan keluasan wawasannya."

Dengan adanya peduli sosial diharapkan Ketika peserta didik terjun ke masyarakat dapat memberikan kontribusi yang nyata terhadap permasalahan. Budaya yang perlu dibangun di 
lingkungan sekolah yang berkaitan dengan karakter sosial yaitu menciptakan interaksi yang baik, saling menghormati dan mendukung satu sama lain.

b. Konsep Sekolah

Menurut Wayne (Soebagio, 2000: 17) Sekolah merupakan interaksi sosial suatu organisasi keseluruhan terdiri atas interaksi pribadi terkait bersama dalam suatu hubungan organik. Menurut Idi (2011: 142) sekolah adalah sebuah Lembaga yang dirancang untuk pengajaran siswa dibawah Lembaga pengawas pendidik. Jadi sekolah merupakan Lembaga yang dirancang untuk kegiatan belajar mengajar dibawah pengawasan guru.

Fungsi sekolah yaitu 1) memberi layanan kepada peserta didik agar memperoleh pengetahuan, 2) memberi layanan kepada peserta didik agar dapat mengembangkan keterampilan, 3) memberi layanan kepada peserta didik agar dapat hidup bersama, dan 4) memberi layanan kepada peserta didik agar dapat mewujudkan cita-cita. (Ali, 2000: 355).

Ciri-ciri sekolah yang efektif menurut Mortimore (supardi, 2015: 12) yaitu sekolah yang memiliki visi dan misi yang jelas, lingkungan sekolah yang baik, kepemimpinan kepala sekolah yang kuat, penghargaan bagi guru dan staf serta peserta didik yang berprestasi, sekolah mempunyai rancangan program yang jelas, guru menerapkan strategi pembelajaran inovatif, evaluasi yang berkelanjutan, kurikulum sekolah yang terancam dan terintegrasi satu sama lain, dan melibatkan orang tua dan masyarakat dalam membantu pendidikan anak-anaknya.

c. Konsep Boarding School

Boarding school adalah rumah pemondokan untuk para peserta didik yang tinggal bersamasama (Khalidah, 2013: 16). Menurut Syahri (2019: 78) boarding school sebagai totalitas interaksi dari seperangkat unsur-unsur Pendidikan yang bekerja sama dan saling melengkapi selama 24 jam. Jadi boarding school adalah suatu cara yang dilakukan pada suatu tempat dimana peserta didik tinggal dalam jangka waktu yang relative tetap bersama dengan guru sebagai pengasuhnya.

Menurut Baedowi (2015: 337) substansi kegiatan peserta didik paada boarding school yaitu bimbingan keagamaan, penguatan kemampuan berbahasa asing, pengembangan bakat dan minat, keterampilan dan sikap prososial.
Karakteristik ideal boarding school yaitu kelebihan secara umum, sistem pembinaan dan pelayanan pendidikan, pendidikan kemandirian dan pembentukan karakter, pendidikan nilai moral, pendidikan nondikotomik yang menghindari terjadinya split personality. (Maksudin, 2013: 106).

Menurut Maksudin (2013: 25) kelebihankelebihan penyelenggaraan sekolah berasrama (boarding school) yaitu 1) ukuran kelas biasanya lebih kecil dari pada kelas-kelas yang ada di sekolah nonboarding. 2) mutu pendidikan akademik dan keahlian khusus bagi peserta didik merupakan prioritas utama. 3) boarding school memiliki standar akademik yang lebih tinggi dan hal itu merupakan tantangan bagi peserta didik. 4) pilihan mata pelajaran atau keterampilan dengan boarding school lebih banyak dan bervariasi serta memiliki cakupan yang cukup luas. 5) sumber daya yang ada pada boarding school seperti perpustakaan, fasilitas teater, sarana olahraga, dan pilihan local bermutu, dan lebih memadai. 6) penasehat pada boarding school biasanya merupakan tenaga ahli yang relevan.

\section{d. Konsep Karakter Sosial}

Karakter sosial berkaitan erat dengan interaksi antar individu manusia, dalam konteks ini peserta didik bagaimana memiliki kemampuan untuk hidup bersama dalam lingkungan sebayanya, orang tua, dan lingkungan masyarakat secara luas. (Funk dalam Harworth, 2004). Karakter sosial adalah perwujudan kepribadian yang melambangkan kualitas karakter bangsa yang terbentuk dari kesatuan hidup antar individu yang membentuk kehidupan suatu masyarakat.

Pembentukan karakter sosial menurut permendiknas yaitu jujur, toleransi, demokratis, semangat kebangsaan, peduli lingkungan, peduli sosial, dan tanggung jawab. Sedangkan menurut Tetep (2017: 43) indikator karakter sosial yaitu 1) Kerjasama, 2) toleransi, 3) kepedulian atau solidaritas.

Menurut Alwisol (2014: 1123) kebutuhan spesifik yang berasal dari kondisi-kondisi eksistensi manusia yang menyangkut karakter sosial yaitu 1) kebutuhan akan keterhubungan dengan pihak lain. 2) kebutuhan akan transendensi atau dorongan untuk menjadi manusia yang kreatif. 3) kebutuhan akan identitas artinya menjadi seorang individu yang unik. 4) kebutuhan akan kerangka orientasi artinya suatu cara yang stabil dan konsisten dalam memandang dan memahami dunia. 


\section{METODE}

Jenis penelitian ini adalah penelitian kualitatif. Metode penlitian yang digunakan adalah deskriptif kualtatif yang bertujuan untuk memberikan gambaran tentang pelaksanaan kegiatan sekolah berbasis boarding school dalam pembentukan karakter sosial peserta didik di SMA Negeri 17 Makassar. Penelitian ini berusaha mengungkap fenomena yang ada dari fakta-fakta yang terjadi pada lokasi penelitian. Dengan demikian penelitian ini menggambarkan atau mendeskripsikan data-data factual yang diperolah dari pihak sekolah terkait dengan pembentukan karakter sosial peserta didik.

Lokasi penelitian dilakukan di SMA Negeri 17 Makassar. Penentuan lokasi ini karena merupakan sekolah yang menjadi sekolah percontohan oleh dinas pendidikan dengan sekolah berbasis boarding school dalam pembentukan karakter sosial peserta didik.

Untuk memudahkan pemahaman tentang fokus penelitian, maka masing-masing diuraikan sehingga Nampak lebih jelas maksud yang dikehendaki dalam penelitian ini. Deskripsi fokus penelitian ini sebagai berikut: (1) Boarding School adalah cara yang dilakukan pada suatu tempat dalam jangka waktu yang relatif tetap bersama dengan guru sebagai pengasuhnya dalam proses pengembangan pribadinya yang terdiri dari bimbingan keagamaan, penguatan kemampuan berbahasa asing, pengembangan bakat dan minat, keterampilan dan sikap prososial. (2) karakter sosial merupakan perwujudan kepribadian yang melambangkan kualitas yang membentuk kehidupan suatu masyarakat yang terintegrasi dengan kegiatan-kegiatan pembinaan keasramaan meliputi jujur, toleransi, demokratis, semangat kebangsaan, peduli lingkungan, peduli sosial, tanggung jawab, dan kerjasama.

Subjek penelitian menggunakan Teknik purposeful sampling dengan pertimbangan, kemampuan informan dalam menyampaikan informasi yang dibutuhkan oleh peneliti dilapangan. Kriteria informan yaitu 1) informan yang memahami dengan baik hal-hal yang berkaitan dengan kebijakan boarding school. 2) informan yang terlibat secara langsung dalam proses pembinaan boarding school. 3) informan yang memiliki peran tertentu dalam proses boarding school.

Sumber data yang digunakan yaitu data primer dan data sekunder. Untuk memperoleh data yang dibutuhkan dalam penelitian, ditempuh teknik pengumpulan data yaitu 1) observasi yaitu kegiatan keseharian manusia dengan menggunakan pancaindra mata sebagai alat bantu utamanya. 2) wawancara merupakan salah satu cara pengumpulan data dalam suatu penelitian. 3) dokumentasi merupakan catatan peristiwa yang sudah berlalu yang bisa berbentuk tulisan, gambar atau karya-karya monumental dari seseorang.

Pemeriksaan keabsahan data yaitu 1) triangulasi dilakukan dengan cara menanyakan hal yang sama dengan sumber yang berbeda. 2) perpanjangan keikutsertaan tidak hanya dilakukan dalam waktu tertentu secara singkat. 3) ketekunan pengamatan dilakukan secara konsisten dengan berbagai cara dalam kaitan dengan proses analisis yang konsisten. dan 4) member check sebagai proses pengecekan data yang diperoleh peneliti kepada pemberi data.

Teknik analisis data yaitu 1) data kondensasi yaitu bentuk analisis yang mempertajam, berfokus, dan mengatur data sedemikian rupa bahwa akhir kesimpulan bisa ditarik dan diverifikasi. 2) display data adalah jalan utama untuk analisis kualitatif yang kuat. 3) penarikan kesimpulan/verifikasi tidak terlepas dari analisis kualitatif yang menafsirkan hal-hal apa yang dimaksud dengan pola mencatat, penjelasan, dan proposisi.

\section{HASIL DAN PEMBAHASAN}

\section{Pelaksanaan Kegiatan Sekolah Berbasis Boarding School dalam Pembentukan Karakter Sosial Peserta Didik di SMA Negeri 17 Makassar.}

a. Bimbingan keagamaan

SMA Negeri 17 Makassar terdapat beberapa kegiatan keagamaan yang diterapkan baik untuk beragama muslim maupun yang beragama non muslim. Bagi yang beragama muslim yaitu shalat lima waktu secara berjamaah dan pengajian rutin setiap hari jumat sebagaimana yang dikatakan oleh ibu Dra. Hj. SB, MM "Shalat lima waktu secara berjamaah dilakukan setiap hari dan pengajian rutin selalu dilakukan oleh peserta didik dengan masyarakat sekitar kompleks sekolah di Masjid pada hari jumat dengan membaca Al-Qur'an". (wawancara 7 Desembar 2019).

Untuk yang beragama non muslim yaitu ibadah, sebagaimana yang dikatakan oleh $\mathrm{AB}$ "ibadah rutin dilakukan di aula setiap hari kamis malam yang didampingi oleh pembina asrama, 
senior atau pemateri yang diundang dari luar sekolah". (wawancara 10 Desember 2019).

Dari hasil wawancara dapat diketahui bahwa kegiatan bimbingan keagamaan yang dilakukan oleh peserta didik yang beragama muslim yaitu shalat lima waktu secara berjamaah dan pengajian rutin yang dilakukan di Masjid oleh peserta didik dengan masyarakat sekitar kompleks sekolah sedangkan bagi yang beragama non muslim yaitu ibadah. Hal ini diharapkan memberikan dampak yang baik bagi peserta didik agar memiliki sikap jujur, toleransi, tanggung jawab serta peduli sosial.

b. Penguatan kemampuan berbahasa asing

Penguatan kemampuan berbahasa asing sangat perlu dilakukan terutama dilingkungan boarding school. sebagaimana yang dikatakan olehbapak Drs. AB, M.Pd dan ibu K, S.Pd "kemampuan berbahasa asing tidak diterapkan dalam kegiatan boarding school karena kebanyakan peserta didik mengikuti bimbel di luar sekolah.” (wawancara 5 Desember 2019).

Dari hasil wawancara dan observasi yang dilakukan bahwa penguatan kemampuan berbahasa asing tidak diterapkan dalam kegiatan boarding school karena Sebagian besar peserta didik mengikuti bimbingan bahasa asing diluar sekolah dengan mengikuti bimbel.

c. Pengembangan bakat dan minat

Peserta didik yang mengikuti boarding school di SMA Negeri 17 Makassar memiliki bakat dan minat yang beragam. Untuk jenis pengembangannya sebagaimana diungkapkan oleh ibu ET, S.PAK, M.Pd "pengembangan bakat peserta didik dikembangkan melalui kegiatan ekstrakurikuler yang telah dibentuk oleh sekolah, peserta didik bebas memilih sesuai dengan minat mereka yang dilakukan setelah jam sekolah atau pada hari libur." (wawancara 15 Desember 2019).

Dari hasil wawancara dan pengamatan dapat disimpulkan bahwa pengembangan bakat dan minat yaitu pada kegiatan ekstrakurikuler yang terdiri dari bidang akademik, seni dan olahraga yang dilakukan setelah jam sekolah atau pada hari libur. Hal ini diharapkan peserta didik dapat bekerjasama serta menumbuhkan sikap demokratis, peduli lingkungan dan peduli sosial.

d. Keterampilan dan sikap prososial

Sekolah yang menerapkan boarding school mengarah pada upaya untuk membekali peserta didik dengan etika. Peserta didik diharapkan mampu menjalin hubungan dengan baik. sebagaimana yang diungkapkan oleh NA "pembina selalu memberikan nasehat dan contoh yang baik sperti bagaimana bersikap kepada teman di asrama, berbicara dengan sopan, saling berbagi, dan saling peduli satu sama lain dengan peserta didik yang lain dan dengan masyarakat sekitar kompleks sekolah." (wawancara 10 Desember 2019).

Dari hasil wawancara dan pengamatan dapat disimpulkan bahwa keterampilan sikap prososial di SMA Negeri 17 Makassar yaitu pembina asrama selalu memberikan contoh yang baik secara langsung dengan masyarakat sekitar kompleks sekolah. Hal ini dilakukan agar peserta didik memiliki sikap jujur, demokratis, peduli lingkungan, peduli sosial, tanggung jawab dan kerjasama dalam berbagai kegiatan yang dilaksanakan.

Pelaksanaan kegiatan melalui penerapan kegiatan asrama yang sudah dijadwalkan seperti bimbingan keagamaan, pengembangan bakat dan minat, keterampilan dan sikap prososial. Selain dari kegiatan tersebut, juga diterapkan beberapa tata tertib dan hukuman yang diberikan kepada peserta didik sebagai rangkaian dari pelaksanaan kegiatan boarding school dalam membentuk karakter sosial peserta didik.

\section{Karakter Sosial Peserta Didik yang Mengikuti Boarding School di SMA Negeri 17 Makassar}

\section{a. Jujur}

Sikap jujur sangatlah penting diterapkan sekolah yang berbasis boarding school. sebagaimana yang diungkapkan oleh ibu K, S.Pd "kejujuran peserta didik masih kurang baik, seperti diterapkannya kantin kejujran dimana kebanyakan peserta didik hanya mengambil saja tanpa membayar apa yang diambil." (wawancara 5 Desember 2019).

Dari hasil wawancara dapat disimpulkan bahwa yang terjadi dilapangan dimana kejujuran peserta didik kurang baik karena masih terdapat peserta didik yang tidak jujur.

\section{b. Toleransi}

Sekolah harus memberikan hak yang sama bagi setiap peserta didik tanpa membedabedakan satu sama lain. Sebagaimana yang diungkapkan oleh DB "dilingkungan boarding school memiliki agama yang berbeda-beda yaitu agama muslim maupun non muslim. Perbedaan ini bukan menjadi halangan dalam melakukan berbagai kegiatan di asrama tetapi membuat kami lebih mengerti dan saling menghargai satu sama lain." (wawancara 10 Desember 2019). 
Dari hasil wawancara dan observasi dapat diketahui bahwa pembina asrama selalu mengajarkan kepada peserta didik agar selalu bersikap toleransi antar sesama baik yang beragama muslim maupun yang beragama non muslim.

c. Demokratis

Demokratis dalam lingkungan boarding school harus selalu terjaga khususnya dalam hal pengambilan keputusan. Sebagaimana yang diungkapkan oleh ibu Dra. Hj. SB, MM "pengambilan keputusan dilingkungan boarding school selalu melibatkan pembina asrama dan peserta didik seperti jadwal kerja bakti, jadwal pembelajaran malam, serta jadwal kegiatankegiatan lain yang diselenggarakan di sekolah." (wawancara 7 Desember 2019).

Dari hasil wawancara dan observasi dapat diketahui bahwa demokrasi dilingkungan boarding school sangatlah bagus karena dalam pengambilan keputusan setiap jadwal kegiatan bukan hanya diputuskan oleh pembina asrama tetapi juga melibatkan peserta didik.

\section{d. Semangat Kebangsaan}

Semangat kebangsaan perlu diajarkan kepada peserta didik agar mereka menghargai para pejuang-pejuang di masa lalu. Sebagaimana yang diungkapkan oleh bapak Drs. AB, M.Pd "guru selalu berusaha menumbuhkan semangat kebangsaan peserta didik dengan membuat kegiatan pada hari nasional agar mereka mengenang para pejuang di masa lalu." (wawancara 5 Desember 2019).

Dari hasil wawancara dapat disimpulkan bahwa guru dan peserta didik selalu memperingati hari nasional dengan menyelenggarakan berbagai kegiatan.

e. Peduli Lingkungan

Peserta didik harus peduli terhadap lingkungan. Sebagaimana yang diungkapkan oleh bapak Drs. H. N, MM "saya bangga dengan peserta didik yang mengikuti boarding school karena mereka betul-betul peduli terhadap lingkungannya terutama lingkungan asrama, mereka selalu bekerja sama menjaga kebersihan serta keamanan asrama." (wawancara 7 Desember 2019).

Dari hasil wawancara dapat disimpulkan bahwa peserta didik selalu peduli terhadap lingkungannya termasuk kebersihan dan keamanan asrama.

f. Peduli Sosial

Peserta didik harus memiliki sikap peduli sosial. sebagaimana yang diungkapkan oleh MNB "kita dan pembina selalu buat kegiatan baksos dengan mengunjungi panti asuhan atau memberikan upah kepada cleaning service." (wawancara 10 Desember 2019).

Dari hasil wawancara dapat disimpulkan bahwa pembina asrama dan peserta didik selalu melaksanakan kegiatan baksos seperti mengunjungi panti asuhan dan memberikan upah kepada cleaning service.

g. Tanggung Jawab

Peserta didik harus memiliki tanggung jawab terutama Ketika mereka berada dilingkungan asrama. sebagaimana yang diungkapkan oleh $\mathrm{M}$ dan DP "kita selalu berupaya melaksanakan tugas yang diberikan oleh pembina asrama dengan menjadi panitia dalam setiap kegiatan." (wawancara 10 Desember 2019).

Dari hasil wawancara dapat disimpulkan bahwa peserta didik memiliki tanggung jawab yang baik, dapat dilihat Ketika mereka diberikan tugas menjadi panitia dalam setiap kegiatan mereka mengerjakannya dengan baik.

h. Kerjasama

Kerjasama sangatlah penting dalam lingkungan boarding school. sebagaimana yang diungkapkan oleh ibu K, S.Pd "Kerjasama peserta didik sangatlah baik yang dapat dilihat Ketika mereka saling membantu dalam mengerjakan tugas sekolah serta melakukan kerja bakti dengan membersihkan kamar mereka maupun lingkungan sekolah." (wawancara 5 Desember 2019).

Dari hasil wawancara dapat disimpulkan bahwa kerjasama peserta didik sangatlah baik karena mereka selalu kompak untuk melakukan segala kegiatan seperti kerja bakti dan menyelesaikan tugas sekolah.

\section{Pembahasan}

\section{Pelaksanaan Kegiatan Sekolah Berbasis Boarding School dalam Pembentukan Karakter Sosial Peserta Didik di SMA Negeri 17 Makassar}

\section{a. Bimbingan keagamaan}

Menghadapi kehidupan zaman modern otak peserta didik tidak cukup hanya dengan ilmu pengetahuan saja tetapi perlu keterampilan dan kecerdasan spiritual. Melalui bimbingan keagamaan yang dilakukan oleh peserta didik yang beragama muslim maupun non muslim membuat mereka mengerti bagaimana berinteraksi dengan baik kepada orang tua, 
pembina asrama, masyarakat maupun dengan teman-temannya.

b. Penguatan kemampuan berbahasa asing

Boarding school merupakan lingkungan yang didalamnya terdiri dari penuntut ilmu sehingga dari segi lingkungan dapat dikatakan baik. Dengan lingkungan yang baik dalam nuansa keilmuan maka untuk menerapkan penguatan kemampuan berbahasa asing sangat kondusif tetapi di SMA Negeri 17 Makassar belum menerapkan karena kebanyakan peserta didik mengikuti bimbel diluar sekolah.

c. Pengembangan bakat dan minat

Setiap individu memiliki karakteristik yang berbeda-beda termasuk dalam bakat yang dimilikinya. Pemberian bakat dilakukan agar peserta didik mengurangi sedikit penat dengan rutinitas dan diharapkan dapat membentuk karakter sosial peserta didik dimana mereka tidak hanya berinteraksi dengan peserta didik yang mengikuti boarding school saja tetapi juuga dengan peserta didik yang tidak mengikuti boarding school dengan saling membantu dalam pengembangan bakat yang diminati.

d. Keterampilan dan sikap prososial

Keterampilan sikap prososial dilingkungan sekolah dapat dibentuk melalui kegiatan dimana peserta didik dilibatkan secara langsung sehingga mereka mendapatkan pengalaman yang dapat menjadi kebiasaan tentang bagaimana berinteraksi dengan orang-orang sekelilingnya yang memberikan suatu dampak positif. Dengan adanya keterampilan sikap prososial di SMA Negeri 17 Makassar diharapkan dapat diterapkan dalam kehidupan sehari-hari peserta didik.

e. Bimbingan belajar

Bimbingan belajar merupakan kegiatan pembelajaran tambahan yang diberikan kepada peserta didik dengan tujuan memberikan kemudahan serta membantu dalam mengatasi persoalan pelajaran yang mereka anggap sulit. Di SMA Negeri 17 Makassar selalu dilakukan bimbingan belajar pada malam hari setiap hari senin dan rabu. Kegiatan ini dilakukan agar peserta didik dapat mengembangkan pengetahuannya serta dapat meningkatkan prestasinya.

\section{Karakter Sosial Peserta Didik yang Mengikuti Boarding School di SMA Negeri 17 Makassar}

a. Jujur
Pentingnya seorang guru menanamkan kejujuran kepada peserta didik karena kunci keberhasilan tidak semata-mata karena keberhasilan seorang peserta didik mendapatkan prestasi yang bagus melainkan sejauh mana mereka dapat membangun dan menanamkan nilai-nilai akhlak dalam kehidupan sehari-hari termasuk kejujuran. Tetapi yang terjadi di SMA Negeri 17 Makassar kejujuran pesrta didik masih kurang baik karena masih terdapat peserta didik yang selalu tidak membayar dalam mengambil barang di kantin kejujuran.

b. Toleransi

Toleransi merupakan sikap atau sifat seseorang untuk memberikan kebebasan kepada orang lain serta memberikan kebenaran sebagai pengakuan hak asasi manusia karena mengedepankan aspek persaudaraan yang berdasarkan kemanusiaan. Toleransi yang dilakukan di SMA Negeri 17 Makassar sangat baik, hal ini dilakukan agar terciptanya keharmonisan, rasa kekeluargaan, rasa kasih saying, rasa tenang dan aman, terciptanya kedamaian serta mempererat hubungan sosial antar peserta didik tetap terjalin dengan baik tanpa membedakan kepercayaan, suku, dan ras.

\section{c. Demokratis}

Demokratis merupakan salah satu karakter yang harus diterapkan yang dapat mendorong kepribadian peserta didik untuk bertindak sesuai dengan nilai-nilai yang terkandung. Dengan adanya sikap demokratis di SMA Negeri 17 Makassar maka peserta didik akan mempunyai sikap nasionalisme dan saling menghargai bila terjdi perbedaan pendapat.

d. Semangat kebangsaan

Semangat kebangsaan merupakan sikap dan tindakan yang menempatkan kepentingan bangsa dan negara diatas kepentingan pribadi atau individu dan dapat melatih peserta didik untuk semangat belajar sehingga mampu menjadi penerus bangsa yang berpendidikan dan berkarakter baik. semangat kebangsaan dapat dimulai dari hal kecil dilingkungan sekitar dengan memperingati hari nasional, hal inilah yang dilakukan di SMA Negeri 17 Makassar yang selalu membuat kegiatan dalam memperingati hari nasional.

\section{e. Peduli lingkungan}

Peduli lingkungan merupakan hal yang penting dalam sebuah kelompok dan lingkungan masyarakat khususnya lingkungan boarding school. kehidupan akan terjadi pada lingkungan yang terbentuk karena adanya rasa peduli, sehingga hal tersebut sangat diperlukan dalam 
kehidupan masyarakat terutama dilingkungan boarding school. hal ini dapat dilihat di SMA Negeri 17 Makassar dengan menjaga kebersihan dan keamanan asrama.

f. Peduli sosial

Peduli sosial sebagai salah satu inti dalam pendidikan karakter karena sikap dan tindakan yang selalu ingin memberi bantuan pada orang lain dan masyarakat yang membutuhkan. Sebagai makhluk sosial tentunya akan ikut merasakan penderitaan dan kesulitan orang lain sehingga ada keinginan untuk memberikan bantuan. Sama halnya yang dilakukan peserta didik boarding school SMA Negeri 17 Makassar dengan membuat kegiatan baksos.

g. Tanggung jawab

Tanggung jawab menunjukkan apakah peserta didik mempunyai karakter baik atau tidak. Orang yang lari dari tanggung jawab berarti tidak memiliki tanggung jawab, jadi unsurnya yaitu keseriusan. Sama halnya yang dilakukan peserta didik di SMA Negeri 17 Makassar mereka dengan serius mengerjakan kegiatan dengan baik.

h. Kerjasama

Kerjasama merupakan hubungan antar beberapa pihak yang saling berinteraksi untuk mencapai tujuan bersama. Kerjasama antar peserta didik perlu ditingkatkan khususnya pada sekolah berbasis boarding school agar mereka memiliki hubungan yang dinamis yaitu saling menghargai, saling membantu, dan saling memberikan dorongan satu sama lain. Adapun manfaatnya yaitu membentuk kekompakan dan keakraban, serta meningkatkan kemampuan berkomunikasi dan menyelesaikan suatu konflik yang terjadi dilingkungan asrama.

\section{SIMPULAN DAN SARAN}

Adapun kesimpulan dari penelitian ini adalah: (1) Pelaksanaan kegiatan sekolah berbasis boarding school dalam pembentukan karakter sosial peserta didik di SMA Negeri 17 Makassar melalui penerapan beberapa kegiatan yang telah dijadwalkan dan wajib diikuti oleh peserta didik khususnya kelas $\mathrm{X}$ yaitu bimbingan keagamaan, pengembangan bakat dan minat, keterampilan dan sikap prososial, dan bimbingan belajar dibawah arahan pembina asrama. Selain kegiatan asrama juga terdapat penerapan tata tertib, pemberian hukuman yang konsisten sesuai dengan tingkat pelanggaran sebagai rangkaian pelaksanaan kegiatan sekolah berbasis boarding school yang dilakukan di SMA negeri
17 Makassar; (2) Karakter sosial peserta didik yang mengikuti boarding school di SMA Negeri 17 Makassar dapat dilihat dari kegiatan yang dilakukan dari segi kejujuran kurang baik karena masih terdapat peserta didik yang tidak memiliki perilaku jujur. Dari segi toleransi, peserta didik saling menghargai dan menghormati tanpa membeda-bedakan keyakinan. Dari segi demokratis, pengambilan keputusan selalu diputuskan bersama. Dari segi semangat kebangsaan, selalu memperingati hari nasional. Dari segi peduli lingkungan, selalu menjaga kebersihan dan keamanan asrama. dari segi peduli sosial, melaksanakan kegiatan baksos. Dari segi tanggung jawab, melaksanakan dengan baik segala kegiatan dan dari segi kerjasama, peserta didik saling membantu melakukan segala kegiatan seperti kerja bakti.

Saran dalam penelitian ini adalah: (1) Pelaksanaan kegiatan boarding school yang dilakukan memberikan pengaruh pada karakter peserta didik terutama karakter sosial sehingga diharapkan para pihak pengelola asrama lebih mengoptimalkan kegiatan yang ada yaitu dengan memperketat pengawasan pada lingkungan asrama, menyediakan program komprehensif yang menyentuh berbagai aspek perkembangan peserta didik, dan melakukan pendekatan personal kepada peserta didik; (2) Melihat karakter sosial peserta didik ditunjukkan dengan menerapkan sekolah berbasis boarding school di SMA Negeri 17 Makassar sangat efektif membentuk karakter sosial peserta didik. Hal ini bisa menjadi acuan dan pertimbangan pemerintah untuk menjadikan sebagai salah satu pendidikan yang lebih dikembangkan seperti memberikan bantuan berupa fasilitas untuk menunjang kegiatan peserta didik di asrama.

\section{DAFTAR RUJUKAN}

Admodiwiro, Soebagio. 2000. Manajemen Pendidikan. Jakarta: PT Ardadizya.

Ali, Muhammad. 2009. Pendidikan untuk Pembangunan Nasional. Jakarta: grasindo.

Alwisol. 2014. Psikologi Kepribadian: Edisi Revisi. Malang: UMM Press.

Baedowi, Ahmad, dkk. 2015. Manajemen Sekolah Afektif. Cetakan 1. Jakarta: PT Pustaka Alfabet. 
Haworth, R. 2004. Are There Differences in Moral and Social Character Between High School Athletes and Non-Athletes. US: UMI.

Idi, Abdullah. 2011. Sosiologi Pendidikan. Cetakan ke 2. Jakarta: PT Rajagrafindo Persada.

Khalidah. 2013. Pendidikan Karakter dalam Sistem Boarding School. Skripsi. Yogyakarta: UIN Sunan Kalijaga Yogyakarta Pers.

Lickona, Thomas. 1991. Education for Character: How Our School Can Teach Respect and Responsibility. New York, Toronto, London, Sydney, Aucland: Bantam Books.

Maksudin. 2013. Pendidikan Islam Alternatif Membangun Karakter Melalui Sistem Boarding School. cetakan ke 2. Yogyakarta: UNY Pers.

Supardi. 2015. Sekolah Efektif: Konsep Dasar dan Praktiknya. Cetakan ke 2. Jakarta: Rajawali Pers.

Syahri, Akhmad. 2019. Pendidikan Karakter Berbasis Sistem Islamic Boarding School (Analisis Perspektif Multididipliner). Cetakan 1. Junrejo-Batu: Literasi Nusantara.

Tetep. 2017. Penanaman Nilai-nilai Karakter Sosial dalam Pendidikan Kewarganegaraan dan IPS dalam
Konteks Perspektif Global. Garut: Jurnal Petik, 2(2).

Zubaedi. 2011. Desain Pendidikan Karakter. Cetakan ke-1. Jakarta: Kencana Pernada Media Group. 